\title{
General Evaluation of the Potential of the Cultural-Historical Heritage Built in the Republic of Moldova
}

\author{
Liliana Jitari \\ Department Engineering, Law and Real Estate Valuation, Technical University of Moldova, Chisinau, The Republic of Moldova \\ Email: liliana.jitari@emi.utm.md
}

How to cite this paper: Jitari, L. (2021) General Evaluation of the Potential of the Cultural-Historical Heritage Built in the Republic of Moldova. Open Journal of Applied Sciences, 11, 633-646. https://doi.org/10.4236/ojapps.2021.116046

Received: May 20, 2021

Accepted: June 19, 2021

Published: June 22, 2021

Copyright (อ 2021 by author(s) and Scientific Research Publishing Inc. This work is licensed under the Creative Commons Attribution International License (CC BY 4.0).

http://creativecommons.org/licenses/by/4.0/

\begin{abstract}
This article analyzes the efficiency of the administration, as well as the way of financing the cultural heritage of the Republic of Moldova through the prism of the legal, institutional and cultural policy framework. Following the research, it was found that in the last 30 years the efficient and transparent management of the material cultural heritage of the Republic of Moldova has not been ensured, which endangers the national cultural heritage. If the current management and financing model does not change significantly in the near future, there is a risk that the cultural heritage of the Republic of Moldova will reach an unrecoverable condition.
\end{abstract}

\section{Keywords}

Cultural Heritage, Historical Monument, Cultural Value

\section{Introduction}

The architectural heritage is one of the most representative pages in the cultural heritage of mankind, the study and protection of which has become a mandatory norm of each country. Knowing the objectives of architecture allows us a better knowledge of the historical past, and their capitalization and preservation must be part of a sustainable legal regime of protection. From the first years after the declaration of the independence of the Republic of Moldova, the state authorities tried to establish such a regime by approving several national normative acts and adhering to various European and international conventions. The Republic of Moldova signed the Association Agreement with the European Union in 2014 and this determined the public administration authorities to change the direc- 
tion of reform and strategic development of the country, including those in the cultural field; by developing and promoting cultural policies based on a permanent intercultural dialogue with the partners of the community countries, in order to develop the cultural diversity, the conservation and the valorization of the national cultural and historical heritage.

After thirty years of independence, we find that the situation in the field of protection of cultural heritage in the Republic of Moldova remains precarious. Although the Parliament of the Republic of Moldova adopted the Law on the Protection of Monuments and the Register of the Monuments protected by the state in 1993, and subsequently ratified a number of conventions in the field, the executive bodies made no effort to implement them. One of the strangest moments in this field was the non-publication of the Register of the Monuments protected by the state, which became a truly normative act only in 2010 . Thus, arising from the legislation in force only the architectural objectives and archaeological sites registered in the Register of the Monuments protected by the state are under the official protection of the state. The state officials' ignorance and the citizens' indifference to our cultural heritage have led to the deterioration and destruction of a number of architectural heritage sites during the three decades of independence [1].

In most countries of the European Union, the values that the Republic of Moldova tends to assimilate, the cultural and historical heritage is protected primarily by proper maintenance, through conservation and restoration interventions. The immovable cultural heritage is considered one of the pillars that ensures the sustainable development of cities, its protection being placed among the essential objectives of urbanism and spatial planning. The current situation in this field is a catastrophic one, given the fact that a large part of the monuments with state protected status is further ruined and destroyed. In this sense, we want to emphasize that if we continue to be irresponsible and indifferent to cultural heritage, we risk losing them irretrievably quite quickly and many of these objectives can be seen only in documents and archive images.

Inspecting and knowing the heritage is part of the human rights to participate in the cultural life of society, as defined by the Universal Declaration of Human Rights. This involves protection and capitalization. The concerns about protecting and capitalizing on cultural heritage have a history of centuries. Over time, various institutional structures have been created, approved by legal commissions that have supported and regulated the process of protecting the movable and immovable cultural property. The concepts in the field have also evolved. Thus, in the 1970s, the notion of "historical monument" was replaced by the term "cultural heritage", the first being since then reserved for the values protected by law. Both the scope of the concept of heritage and the concept of historical monuments have expanded considerably. New approaches have emerged, new types of heritage have been highlighted internationally, new ways of valuing historical monuments have been successfully implemented [2]. 


\section{The Development of Cultural Heritage of the Republic of Moldova during the Period of Independence}

As it was mentioned, culture plays a key role in the development and progress of any state. In the Republic of Moldova, however, throughout the period after 1991, the field of culture was neglected, being assigned a fragmentary and marginal role in the development of society. The Republic of Moldova has failed to create a new policy for the development of culture in accordance with current economic, social and political realities.

The formation of the institutional and regulatory framework of culture took place very slowly, unevenly and broadly it can be seen that it does not correspond to current economic and social realities. The policies underlying the management of this sector have focused too little on the use of culture development mechanisms related to the market economy and have not taken into account the current demographic trends.

Cultural development policies have also been insufficiently integrated with other important sectors of societal development, primarily with the economic sector, education and other horizontal areas such as the environment, youth and sports policies, social assistance. Because of this, the role of culture in the development of the country was underestimated. In turn, this underestimation led to inadequate attention from the Government to the needs of this field, first of all, from a managerial point of view and not necessarily from the volume of the allocated resources. The consolidated resources allocated to culture, measured as a share of GDP or total expenditure of the national public budget are quite close to the indicators in other European countries ([3], p. 14).

A number of factors have recently contributed to the irretrievable destruction of hundreds of monuments and objects of national cultural heritage, such as: the lack of an adequate legal and regulatory framework, the lack of prompt involvement of legal institutions to stop violations of the law, the lack of a framework capable of managing cultural heritage, the lack of coherent state policies and cooperation between different government institutions of different levels, the lack of a strategic plan for heritage development and an efficient cultural heritage management system, the lack of specialists in the field of restoration of monuments, poor funding and the lack of political will to change this situation.

The immovable cultural heritage of the Republic of Moldova includes a wide range of historical and cultural monuments from various historical epochs. So far, on the territory of the Republic of Moldova have been identified over 12000 monuments of history and culture, of which 5206 are included in the Register of monuments of the Republic of Moldova protected by the state. Of the total number of monuments, about 8000 represent archeological sites, about 100 of them are earthen fortresses, 3 medieval walled fortresses, 6 medieval cities (Orhei, Lăpuşna, Tighina, Soroca, Căușeni, Chișinău), 788 churches, 129 mansions and many historical cities from the 19th century (Bălți, Cahul, Chişinău, Orhei, Soroca, Tiraspol) ([4], p. 26). 
$10 \%$ of the monuments of the Historic Center of Chișinău have been demolished and $30 \%$ of the built heritage is considered endangered. Chișinău risks losing the Historic Centerif the pace of demolition and degrading interventions on the architectural heritage does not stop ([3], p. 8).

At present, there is no clear concept of development and propagation of the cultural heritage of the Republic of Moldova for increasing the visibility of the tangible and intangible cultural heritage in the national and international public space.

From the data presented publicly, it is found that there are deficiencies in the efficient and transparent management of cultural heritage.

Among them, the following could be listed ([3], p. 47):

1) Privatization at symbolic prices, in rental conditions, of some goods from the national cultural heritage by natural and legal persons, in violation of some imperative norms (for example: Bucharest 62, Rîşcanu-Derojinschi Urban Mansion);

2) Inefficient management of public property. The elements of legality and transparency, as well as the principle of competitiveness did not meet the legal requirements, and the activity related to the leasing of public heritage carried out within the entities did not fully contribute to the efficiency of its management according to expectations (for example: "Village Museum" Complex, "Balioz Mansion” Museum Complex, Rîşcanu-Derojinschi Urban Mansion, etc.);

3) The leasing mechanism is affected by the non-implementation of a system of financial management and functional control (for example: "Luceafărul" S.E. Republican Theater, 52 Eminescu Street, monument with state protected status, A. D. Inglezi's urban mansion);

4) By taking some irrational and inappropriate decisions by the Privatization Commission within the JPA, as well as by other bodies responsible for the process of de-ethnicization of public property, has led to the alienation of state-owned cultural property in private ownership at symbolic prices with the leasing prices. The new owners transferred the privatized goods in lease to public entities at clearly higher prices, thus their investments being recovered within up to 1 year, subsequently they are obtaining considerable profits on account of public property;

5) There were cases of reduction of the rent payment, conditioned by the decrease of the areas leased, as well as by the decrease of the value of some coefficients that were the basis for determining the annual rent. The non-registration of the property right over some cultural goods, as well as the corresponding non-reflection in the accounting records of all the lands owned by them (for example: "Luceafărul" S.E. Republican Theater, 52 Eminescu Street, monument with state protected status, A.D. Inglezi's urban mansion);

6) Inadequate evaluation by the cadastral bodies of some immovable cultural property transferred in lease, for the purpose of their taxation;

7) The non-execution of the contracts by some economic agents, in conditions 
of location, usufruct and superficies laws, concluded with some institutions subordinated to the Ministry of Culture, regarding the restoration and reestablishment of some objectives that are part of the cultural heritage, which led to the degradation of architectural monuments ("Balioz Mansion" museum complex from Ivancea village);

8) Some contracts concluded by the Ministry of Culture and the subordinated institutions with some economic agents regarding the restoration and reestablishment of some architectural monuments did not provide distinct clauses for the fulfillment of the assumed commitments, fact that determined the non-obtaining of the established advantages (Balioz Mansion, Kligman House, Herța House);

9) The restoration and reconstruction works of the Museum Complex "Balioz Mansion" were carried out without a building permit, and as a result of their delay and interruption for 3 years, several shortcomings were revealed, including degradation of some buildings;

10) The land, with an area of $175.3 \mathrm{ha}$, was distributed by the National Museum of Ethnography and Natural History for the purpose of preserving and training the monuments of national culture. By building the "Village Museum", itacquired another aspect along the way, being transformed into an unauthorized rest area, for which people have to pay. Unfortunately, these incomes are not registered in the accounting records of the National Museum of Ethnography and Natural History;

11) The formation of debit debts, including those with the expired term, as a result of non-payment of rent and communal services within the terms established by the lease contracts and failure to take the necessary measures against the debtors;

12) The transmission/leasing mechanism, implemented by the sponsors in the field of public property management, carried out without an efficient management and in an inefficient way (for example: The Museum Complex "Village Museum", the Museum Complex "Balioz Mansion", etc.).

The officials involved in the public property management process did not ensure a good governance of the public heritage under the management of public entities, state enterprises and commercial companies with full or majority public capital. There are still some reserves in the lease to ensure an efficient management and control system in the chapter of the implementation of the giving/taking mechanism. The Government has to elaborate and implement some distinct and exhaustive regulations, meant to establish sufficiently the lease relations, as well as to restrict both the current way of leasing the uninhabitable spaces from the private sector, and the one of privatizing the uninhabitable rooms, the leaseadpublic property, in order to improve the situation and ensure the efficient administration of the public heritage, the economical and efficient use of public funds.

It is important to mention the fact that according to the provisions of art.3, point 5), letter b) of Law no. 627-XII from 04.07.1991 "On privatization", the 
objectives that are part of the national cultural heritage, included in the Register of monuments of the Republic of Moldova protected by the state, are not subject to privatization, which at the moment is not respected and it is not applied in practice.

The precarious condition of the movable heritage was determined mainly by the level of economic development and the unstable socio-political situation in the country in the last 30 years. A real danger for the architectural and natural heritage of the Republic of Moldova is the pressure of real estate investments and unauthorized constructions that have appeared with the economic growth.

In 2010, the Agency for Inspection and Restoration of Monuments (AIRM) began inspecting and evaluating the real situation of architectural monuments included in the Register of State Protected Monuments to establish the state of conservation, protection and enhancement of the national cultural heritage of the Republic of Moldova. The urban development of Chişinău, doubly accelerated compared to the rest of the country, resulted in the imposing destruction of the national real estate heritage. The "Register of monuments of national and municipal importance", approved by the Chişinău's City Hall in January 1995, includes 977 municipal historical monuments.

As a result of the evaluation of the architectural heritage of the Nucleus of the Historical Center of Chisinau, carried out by AIRM, it was found ([3], p. 49):

1) 80 architectural monuments were demolished (of which 44 were demolished during 1993-2006, and 36 objectives were demolished during 2006-2012);

2) 17 historic buildings are in an advanced state of ruin;

3) 160 cases of illegal interventions that damaged the authenticity of the monuments.

In Chişinău, 254 national and local real estate monuments from a total of 977 monuments suffered due to the non-compliance with the legislation in force.

The historic center of Chişinăucontinues to be seen as a space for urban experiments, the historic buildings here being treated as an embarrassing obstacle to progress, which is confused with the destruction of the historic fund of buildings and its replacement with new buildings, considered to be the only ones "conforming to the modern lifestyle". Many downtown homeowners, awaiting imminent demolition or foundation rebuilding, are only looking for opportunities to sell their historic buildings and land, avoiding investing in repairs. At the national level, the evaluation carried out by AIRM in the period 2009-2011, on 788 monuments from 366 localities (29 districts), revealed major dysfunctions and vulnerabilities in the field of real estate in the Republic of Moldova, as follows ([1], p. 34):

$>$ about $15 \%$ of buildings and historical sites were demolished;

$>40 \%$ of buildings and historical sites are in a state of advanced degradation;

> 111 churches were mutilated by the degrading interventions, without the permission of the authorities invested by the legislature with responsibilities for authorizing such interventions; 
$80 \%$ of the 49 boyar mansions with the status of protected monument of national category are in a state of ruin;

18 wooden churches registered in the Register of state-protected monuments were demolished during 1993-2012;

> 4 wooden churches are in a state of advanced degradation;

20 buildings of civil architecture are in a degrading condition;

$>50$ public monuments are in an unsatisfactory condition;

$>31$ churches from various localities of the republic are currently in an unsatisfactory situation and do not meet all the norms of preventive conservation. Likewise, in most of the historical monasteries protected by the state, some interventions were operated that seriously damaged their originality and monumental value;

8 monasteries in the country are in an unsatisfactory state, over 20 in a wretched state.

On 11.07.2012, the "National Development Strategy, Moldova 2020" was approved by the Parliament of the Republic of Moldova. The field of culture, implicitly, the field of cultural heritage, does not find its place among the eight development priorities of the country.

In these conditions, the Ministry of Culture elaborated the Culture Development Strategy "Culture 2020", approved by the Government of the Republic of Moldova on 29.01.2014. It is the first strategic document in the field of culture in the Republic of Moldova, since the declaration of independence in 1991. One of the four general objectives of the Strategy is "Safeguarding the national cultural heritage". Among the basic actions to be taken to achieve this objective are [5]:

- Finalizing the national normative framework in the field of cultural heritage protection by adopting the Law on the protection of historical monuments, which contains for the first time, for the national legislation, detailed provisions including those regarding the protection of historic cities/protected built areas. The necessary amendments to the Criminal and Administrative Codes of the Republic of Moldova are to be made, respectively.

- Finalizing the national institutional framework in the field of cultural heritage protection.

- The documentation and inventory of the built cultural heritage, including the protected built areas/historic cities, by creating the national institution responsible for the evidence.

- Creating the market of services for the conservation/restoration of the built cultural heritage-by forming the national system for training staff in the field; by ensuring a competition for access to the provision of design and operation services for conservation/restoration works based on professionalism/knowledge and specialization in the field.

- The creation of the cultural heritage protection system within the territorial-administrative units.

The strategy did not establish separate actions against the protected built-up 
areas and historic cities. To solve the existing problems, it is important to promote the perception of the built cultural heritage, including the urban heritage of historic cities, as an important resource for sustainable development of localities, and not as an "embarrassing obstacle to progress" ("progress" is usually, associated with wide streets, large urban constructions, made of glass and concrete, which "inevitably" must replace the constructions of historic centers).

That perception has been educated over the past few decades against the background of the demolition of the Soviet system of protection of built heritage and not building anything new.

Overcoming the situation is possible by building a new system for the protection of the built cultural heritage in the Republic of Moldova; by integrating it in the urban development plans of localities (establishing borders, buffer zones, a management plan, etc.), according to the principles set out in documents (books, conventions, resolutions) in the field of the Council of Europe and UNESCO and in accordance with the European best practices.

By implementing the Strategy, the cultural sector was to become a viable and impactful area in the economy and social life of the entire country. The mission of the Strategy was to provide the cultural sector with a coherent, efficient and pragmatic policy framework, starting from the priorities identified in the document. The strategy took into account the needs of the sector and of human capital in the fields. By December 31, 2020, the Republic of Moldova would have a consolidated, independent and creative cultural sector, a cultural heritage protected and integrated into the national and regional public policies, including sustainable development activities: educational, social, economic, tourism and the environment.

The modernization of cultural institutions and digitization in the arts and culture sector is one of the objectives of the National Strategy for the Development of Culture of the Republic of Moldova/Culture 2020. It aimed to ensure the real and virtual circulation of cultural products. The basic objective of the Strategy is to make the information system of the cultural sector practical.

Among the priority actions of the Strategy are:

- Digitization of cultural heritage;

- Development of a single information system in the field of culture.

The National Program for the computerization of the cultural sphere for the years 2012-2020 was also approved in 2012. The objective of the program was to digitize, in proportion of $75 \%$, the tangible and intangible cultural heritage of the Republic of Moldova by 2020. Another document containing provisions related to culture is the National Strategy for the development of the information society “Digital Moldova 2020". The national program for computerization of the sphere of culture for the years 2012-2020, also provided for the creation of the infrastructure and information spaces in the field of culture, necessary for the provision of electronic services in the field of culture.

These policies in the field of culture and cultural heritage have not been suc- 
cessful due to lack of financial coverage. If these policies had been implemented practically, today we would witness an advanced level of development of the cultural sector and the impact on the economy and social life of the whole country.

In this context, the governance objectives that could improve the cultural heritage policy are:

1) Promoting culture, as a primary factor in preserving and developing the national identity;

2) Promoting national cultural values, as a component part of the European cultural heritage.

In this sense, the priority actions are:

1) Protecting and integrating the national cultural heritage in the system of European cultural values by ensuring the existence of a strategic vision on the development of culture in the medium period of time. Ensuring the rehabilitation and maintenance of historical and cultural objects based on public-private partnerships and digitization of cultural heritage of the Republic of Moldova;

2) The development of the legal framework regarding the protection, conservation and enhancement of monuments of culture, history and archeology, as well as in order to stimulate the active involvement of individuals and legal entities in activities of preservation, capitalization and development of national cultural heritage;

3) The elaboration of the unique Strategy for the development of culture and protection of the national cultural heritage, which will include a program for the restoration and capitalization of the monuments of culture and history, in order to support the cultural establishments, to rehabilitate the infrastructure connected to economic, social, educational and urban development programs;

4) Improving the capacity to manage the national cultural heritage by creating an adequate management;

5) Coordinating the works regarding the conservation and restoration of the built cultural heritage;

6) Digitization of the national cultural heritage, including in libraries.

\section{Analysis of the Current Situation Regarding the Cataloging of the Cultural Heritage}

The legislation in force on the cultural heritage of the Republic of Moldova does not provide a unique system for cataloging real estate cultural heritage. The classification system is based on the registration of assets in the Register of Historical Monuments, based on the proposal of the Ministry of Culture. Although in recent years the legislation has been repeatedly completed and updated, the procedure for the registration of cultural property remains unclear [6].

The classification mechanism is confusing, the procedures for identifying, describing and cataloging the assets are quite complex and are not applied or they are applied only to a minimum. In this context, any digitization project is vir- 
tually impossible due to the lack of homogeneous databases, infrastructures and technological systems.

In addition, the fragmented nature of competencies and regulations between the different protection systems weakens the whole system. Thus, it is currently difficult to develop a common digital documentation system that could make the necessary data available to the various stakeholders.

One of the worst problems is the lack of an efficient link between the registers and the cadastral system. This link would strengthen the practice of protecting private property.

The lack of a unified cataloging system makes it virtually impossible to implement the information systems connected to other national databases, preventing the creation of effective urban and spatial planning tools or the development of risk maps. In Chişinău, there is an obvious lack of concordance between the Register of monuments of the Republic of Moldova protected by the state and the Register of Monuments of local importance of Chişinăumunicipality, which assigns a different classification (national or local) to the same monument. Due to this many errors are committed in the record of real estate heritage and its protection [7].

Moreover, the data included in these inventories were not designed for IT applications, so they are not suitable for homogeneous transposition into a digital information system. In order to overcome this problem, professional data analysis is mandatory. It is also necessary to address the spatial analysis of data, which is not yet regulated.

In order to create an efficient information system of the built cultural heritage, it is essential to adopt a progressive and a modular unitary cataloging system that applies to all types of immovable cultural heritage.

Modularity would allow to respond to the diversity of goods, offering a series of specific modules adapted to different types (archaeological, monumental, historical...) within a unified data structure. The adoption of databases for asset identification (administrative data, geo-referencing, location, cadastral data, properties, metadata) would be of particular importance. Such an approach to the cataloging process would also facilitate the access to the various levels of detail required for the procedural steps, from the first identification of the asset to the proposal for listing, protection and monitoring.

Cultural heritage management is a complex set of legal and institutional frameworks, capacities, resources that, together, ensure the physical protection of property, adequacy in related management activities and public satisfaction.

The catalog aims to identify and describe the cultural heritage for which the artistic, historical, archaeological or ethno-anthropological importance has been recognized. The general catalog of cultural heritage collects and centralizes the descriptive and administrative data of protected monuments. It also collects the data on monuments that are not yet registered and those that are protected for research purposes. 
The general catalog of cultural heritage would be a suitable tool for the protection and consolidation of cultural heritage, planning interventions for conservation and is the fundamental level of knowledge for spatial planning and for effective prevention of natural and man-made threats.

In Moldova, the heritage protection policy and decision-making processes include various degrees of vertical autonomy and low levels of horizontal relations [6]. On the one hand, this is due to the lack of adequate technical equipment, and on the other hand-the lack of easily accessible and common basic information on heritage. This constraint could be exaggerated if the basic heritage information were more easily accessible in a common, coherent way through up-to-date information technologies.

The implementation of an autonomous IT cataloging system for the built heritage of Moldova is of strategic importance in the perspective of a general policy for the development of Moldovan institutional and administrative assets.

The IT cataloging system for the built heritage of Moldova will be a relational integrated spatial database, which will allow users to explore, overlay and process the information about cultural assets and the potential risk factors. It will provide heritage managers with a technological tool to support scientific and administrative activities. This system will collect data on any type of real estate, both monumental and archaeological, regardless of classification and degree of protection, and will be an operational tool to support the decision-making process in the protection of cultural heritage, spatial planning and control. The IT cataloging system for the real estate heritage of Moldova will be based on a database of registered and unregistered monuments and archaeological assets. The database will consist of:

1) Archaeological sites;

2) Monuments. Both registered and unregistered.

All monuments and archaeological assets will be analyzed on the basis of a Unified Inventory Form and files on Monuments and Archaeological Assets. They are based on the data set stipulated in the following:

$>$ Order No. 380 from 27.12.2016 on the Regulation on the National Register and Local Registers of Public Monuments;

$>$ Regulation on the evidence and classification of the archaeological heritage, Order of the Minister of Culture No. 126 from 25.04.2013 has already been included in the system.

The IT cataloging system for the real estate of Moldova will be a section of the Moldovan National geospatial data fund, managed by the Agency for Land Relations and Cadastre (ARFC). The layer will collect the data already existing in the system of both the Agency for Inspection and Restoration of Monuments and the National Archaeological Agency.

The application "EPatrimoniu" created by the Agency for Inspection and Restoration of Monuments on the platform http://www.geoportal.md/ is an example of promoting the immovable cultural heritage through information tech- 
nologies, which currently works and provides online data of over $1000 \mathrm{monu}-$ ments in the real estate heritage of the Republic of Moldova. The online platform http://www.monument.sit.md/ launched by the Association "SIT" is, in the same context, an invaluable contribution in the field of research and promotion of the architectural heritage of Chişinău. This platform in collaboration with the Publishing House "Arc" launched in 2010 the album entitled "The historical center of Chişinăuat the beginning of the XXI century. The repertoire of architectural monuments" [8].

\section{Conclusions}

The Republic of Moldova has a considerable cultural heritage that needs urgent capitalization and consolidation. The Government of the Republic of Moldova has assumed as a priority the alignment and functioning of institutions in the field of cultural heritage to European standards through its long-term programs and objectives [3]. At the same time, after the examination of the current situation in the localities of Moldova, regarding the technical condition of the cultural heritage, it can be concluded that in these 30 years of independence, efficient and transparent management of the cultural heritage has not been ensured. A major problem is the conservation and protection of the immovable (architectural) cultural heritage, which has been affected to a greater extent in recent years.

The legal framework in the field of cultural heritage has not been accompanied by practical reforms, and the "preservation of heritage" has taken place only on paper, without having a real impact in terms of its protection and enhancement. The lack of coherent state policies, the lack of a strategic plan for heritage development, the lack of an efficient management system of cultural heritage, the lack of specialists in the field of restoration, precarious financing and the lack of political will contributed to the irretrievable destruction of hundreds of monuments and vestiges of the national cultural heritage.

About $10 \%$ of the monuments of the Historic Center of Chişinău have already been illegally demolished, and $30 \%$ of the immovable cultural heritage is considered endangered, with a new case of demolition being registered every month.

The poor financing of programs for the protection and enhancement of cultural heritage, but also the inefficient management of heritage is largely due to the inefficient mechanism of financing the cultural sector, which remained the same as in the Soviet period. Although the allocations for cultural heritage have increased from year to year, the state's financial policy regarding the safeguarding of cultural heritage focuses on strategies and objectives for survival and not on its development.

The recommendations for improving the situation in the field of capitalization of cultural heritage would be the following:

1) Adapting the legislative framework to the real and current needs, including the International norms in the field, in order to stop the degradation and de- 
struction of the inherited cultural heritage. It is necessary to draft a new law on the protection of historical monuments in the context of international experience in the field and compliance with the obligations of the Republic of Moldova to European partners and UNESCO, which will replace the current Law on the Protection of Monuments from 1993;

2) Modifying the provisions of the Law on Authorization in Constructions, in order to make impossible the issuance of permissive documents for interventions at monuments by the Local Public Administration, without the prior mandatory approval of the National Council of Historical Monuments attached to the Ministry of Culture;

3) The Republic of Moldova must honor its commitments under international treaties and conventions in the field of cultural heritage;

4) Elaborating the National Strategy on safeguarding the cultural heritage of the Republic of Moldova;

5) Correcting the General Urban Plan of Chișinăuand bringing its provisions for the central historical part of the city, in accordance with its status as an area of national category built and protected;

6) Promoting fiscal and financial policies for the benefit of cultural heritage;

7) Establishing some integrated plans for the protection of cultural heritage, in accordance with the principles of the International Conventions to which Moldova is a party.

A long-term solution for financing the cultural heritage could be the public-private partnership. The amendment of the Law on Philanthropy and Sponsorship will stimulate private companies and economic agents to invest in the field of restoration of cultural heritage, benefiting from fiscal facilities.

At the same time, it is necessary to create the infrastructure and capacities to receive visitors in areas with cultural potential, thus promoting cultural values and products for cultural consumption.

\section{Acknowledgements}

This paper was prepared and the research was carried out within the project 20.80009.0807.34 "Increasing the value of architectural heritage of the Republic of Moldova" implemented by the Technical University of Moldova.

\section{Conflicts of Interest}

The author declares no conflicts of interest regarding the publication of this paper.

\section{References}

[1] Ministerul Culturii al Republicii Moldova Agenția de Inspectareși Restaurare a monumentelor (2011) Patrimoniul cultural al Republicii Moldova de la realitate la necesitate.

https://slideshare.net/ghenador/patrimoniul-cultural-al-republicii-moldova-de-la-r ealitate-la-necesitate 
[2] Ploșniță, E. (2020) Muzeificarea-opurtunitate de valorificare a patrimonilui imobil. Patrimoniul Cultural: Cercetare, Valorificare, Promovare, 1, 22-29. https://ibn.idsi.md/sites/default/files/imag_file/22-29_8.pdf

[3] Evaluareaeficiențeișitransparențeiutilizăriiresurselorpublicealocateculturii (2013) Evaluarea eficienței și transparenței utilizării resurselor publice alocate culturii. Chișinău, 43-56.

https://www.expert-grup.org/en/biblioteca/item/download/986_838c36e2842bfbfb7 5f95d57f10a368c

[4] Musteață, S. (2011) Patrimoniul Cultural al Republicii Moldova-Probleme de Legislațieşi Management, Patrimoniul Cultural al Republicii Moldova: de la realitate la necessitate. AIRM, 26-28.

[5] Hotărîrea, G. (2014) Strategia de dezvoltare a Culturii „CULTURA 2020”. https://www.legis.md/cautare/getResults?doc_id=60253\&lang=ro

[6] Proiectul Twinning (2016) „Suport pentru patrimoniul cultural în Republica Moldova, prin păstrarea și protecția acestuia” MD 13 ENPI OT $0116(\mathrm{MD} / 26)$, implementat de către Italia și Moldova, în cadrul componentei 4 „Suport direct instituțiilor moldovenești din domeniul protejării patrimoniului”. 23-29.

https://mecc.gov.md/sites/default/files/05_tw_md_raport_activitatea_4.1.pdf

[7] Elaborarea Registrului Monumentelor Imobile de Importanță Locală din mun. Chişinău (2011) Vol. I, Memoriu Explicativ, Direcția Generală Arhitectură, Urbanism şi Relații Funciare, IMP “Chişinăuproiect". 7-9.

[8] Stăvilă, T. (2011) Tezaurul Arhitectural al capitalei. Akademos, 1, 162. 